\title{
Scale Insects and Mealybugs on Ornamental Plants ${ }^{1}$
}

\section{Eileen A. Buss and Jay Cee Turner²}

Scale insects are the most serious pests of many ornamental plants. There are 13 families of scales in Florida, the most common being armored scales, soft scales, and mealybugs. Scales cause damage by sucking plant fluids from leaves (Figure 1), stems, and sometimes roots. Some species feed on the underside of leaves, which can appear as stippling (small yellow spots) or chlorotic lesions. Heavily infested plants look unhealthy and produce little new growth. Heavy infestations can cause extensive leaf yellowing, premature leaf drop (defoliation), branch dieback, and plant death.

\section{Biology and Behavior}

Life cycles of the various scale species differ somewhat, but a generalized life cycle is as follows. The eggs are laid beneath the wax coverings, ovisacs, or beneath the adult female (Figure 2). Eggs generally hatch in 1 to 3 weeks. The newly hatched nymphs (crawlers) move around the plant until they find a suitable feeding site (Figure 3). Wind may also transport crawlers to new hosts. Nymphs insert their straw-like mouthparts into the plant and begin to feed and grow. Males of many species develop wings as adults and fly to locate mates.

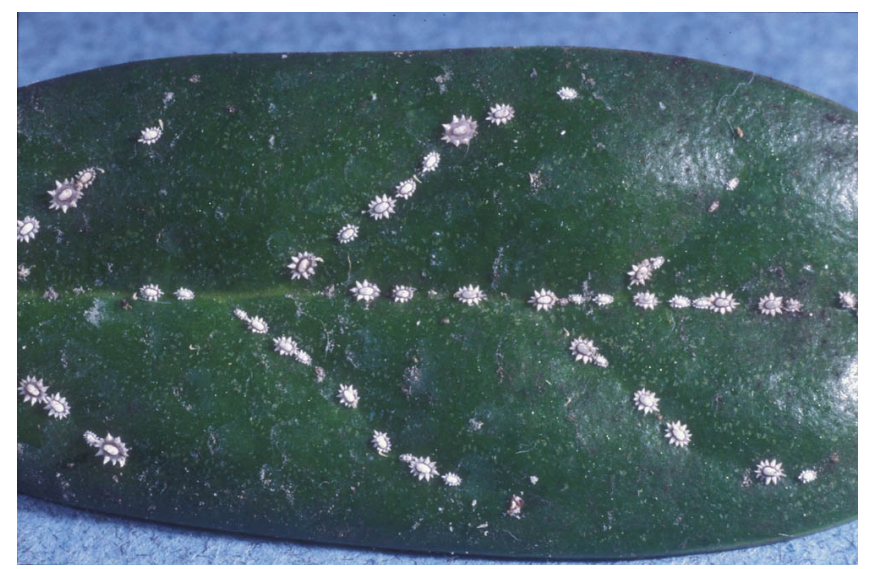

Figure 1. Florida wax scales along leaf veins. Credits: Lyle Buss, University of Florida

\section{Armored Scales (Diaspididae)}

Over 175 species of armored scales occur in Florida. They are distinct from other types of scales because they secrete a waxy covering over their bodies that is not attached to the body. The scale lives and feeds under this covering. They range in size from 1/16 to 1/8 inch in diameter and can be almost any color and shape, depending on the species. Some adult female armored scale shapes are shown in Figure 4. Male covers are generally more elongate

1. This document is ENY-323 (MG005), one of a series of the Department of Entomology, Florida Cooperative Extension Service, Institute of Food and Agricultural Sciences, University of Florida. Date first printed: October 1993. Revised: June 2006. Please visit the EDIS Website at http://edis.ifas.ufl.edu.

2. Eileen A. Buss, assistant professor, and Jay Cee Turner, graduate student, Entomology and Nematology Department, Cooperative Extension Service, Institute of Food and Agricultural Sciences, University of Florida, Gainesville, 32611.

The use of trade names in this publication is solely for the purpose of providing specific information. UF/IFAS does not guarantee or warranty the products named, and references to them in this publication does not signify our approval to the exclusion of other products of suitable composition. All chemicals should be used in accordance with directions on the manufacturer's label. Use pesticides safely. Read and follow directions on the manufacturer's label. 


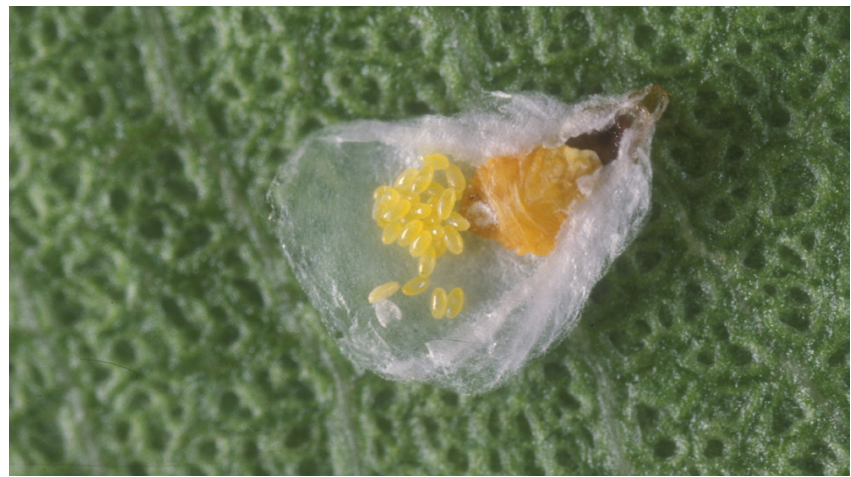

Figure 2. False oleander scale female, turned over to show eggs and female body. Credits: Lyle Buss, University of Florida

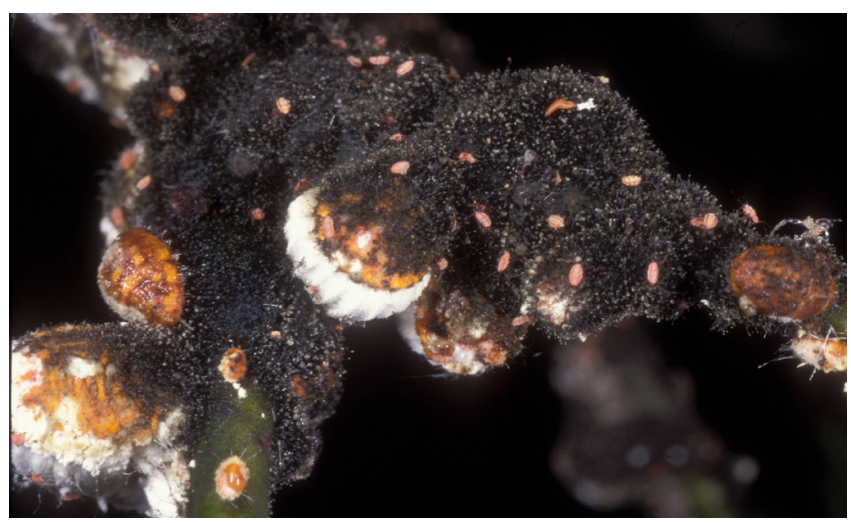

Figure 3. Cottony cushion scale crawlers on sooty mold-covered adults. Credits: Lyle Buss, University of Florida

and smaller than that of females (Figure 5). After molting, adult males are tiny, winged, gnat-like insects and are rarely seen. Armored scales do not secrete honeydew.

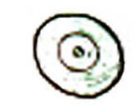

Circular

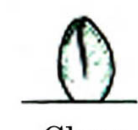

Clam

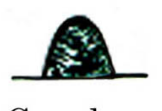

Gumdrop

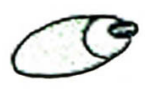

Elongate

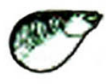

Pear
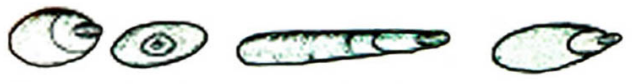

Oval
Oval
Long, slender

Oystershell

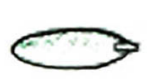

Shield
Figure 4. Shapes of adult female scales.

\section{Soft Scales (Coccidae)}

Over 60 species of soft scales occur in Florida. Soft scales (Figure 6) also secrete a waxy covering, but it is attached to their bodies. Soft scales vary widely in color, size, and shape. They range from $1 / 8$

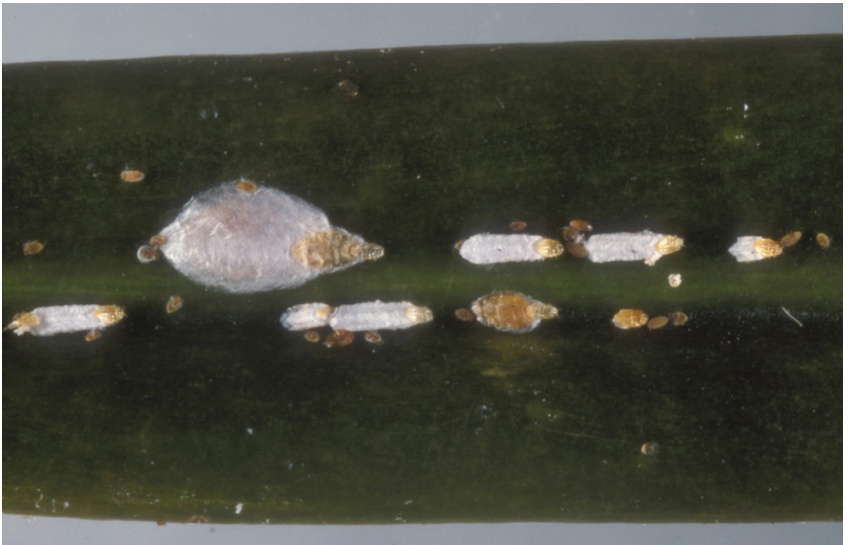

Figure 5. Cycad aulacaspis scale adult female, male covers, and nymphs. Credits: Lyle Buss, University of Florida

to $1 / 2$ inch in diameter and may be nearly flat to almost spherical in shape. Because soft scales consume so much plant sap, they excrete a lot of sugary liquid, called honeydew.

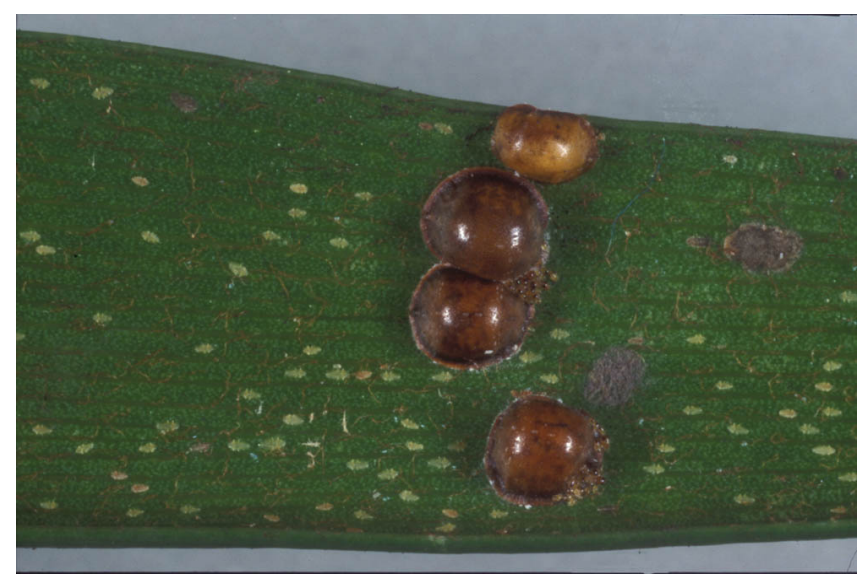

Figure 6. Hemispherical scale on coontie. Credits: Lyle Buss, University of Florida

\section{Mealybugs (Pseudococcidae)}

Mealybugs are soft-bodied insects that are often covered with cottony white filaments (Figure 7). They are about $1 / 8$ inch long, with pinkish or yellowish bodies. These insects can move throughout their lives. They infest all plant parts: feeder roots, root crowns, stems, twigs, leaves, flowers, and fruits. Injured plants have discolored, wilted, and deformed leaves.

\section{Sooty Mold}

Soft scales and mealybugs excrete large amounts of honeydew which provides an excellent medium for 


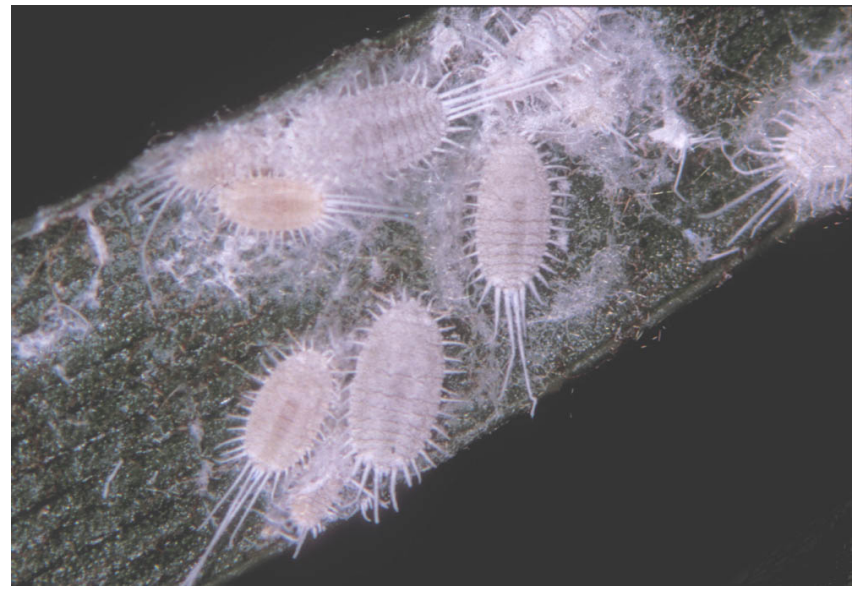

Figure 7. Mealybugs. Credits: James Castner, University of Florida

the growth of a black fungus called sooty mold (Figure 8). Besides being unattractive, sooty mold interferes with photosynthesis and somewhat slows plant growth. Sooty mold usually weathers away following control of the insect infestation. Ants feed on the honeydew and when ants are observed, plants should be examined closely for these sucking pests.

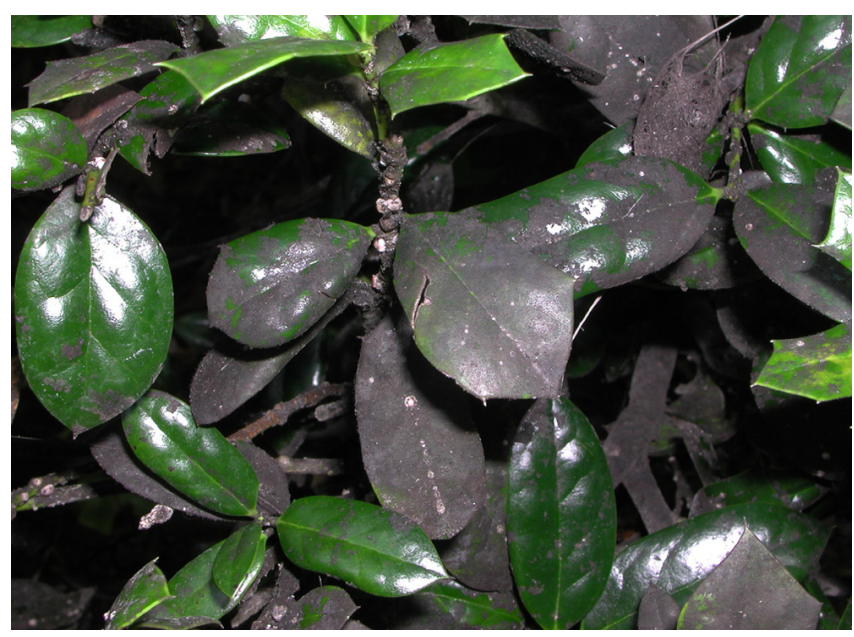

Figure 8. Sooty mold on holly, resulting from a Florida wax scale infestation. Credits: Eileen Buss, University of Florida

\section{Detecting Infestations}

Scale infestations are often not noticed until leaf yellowing, dieback, or sooty mold are apparent. Monitoring weekly throughout the year helps prevent severe problems from occuring. Carefully look at the undersides of leaves and stems for scales. Use a 10 power-magnifying glass, if needed. Scales may look like fungal growths or plant parts, and they may be hidden in bark crevices or leaf axils.

\section{Cultural Control}

To minimize scale problems, inspect plants before purchase or installation. If some scales are found, prune off the infested branches or leaves. Destroy any culled or discarded plant material, and thoroughly clean the area where the infested plants were located (especially important in greenhouses and nurseries). Scale insects often thrive in warm, humid environments, so increase air flow or decrease plant density in the area to make conditions less conducive. Avoid over-fertilizing; scale insects often lay more eggs and survive better on plants receiving a lot of nitrogen.

\section{Biological Control}

Under natural conditions, predators (ie., ladybird beetles, green lacewings) and parasitoids (ie., tiny wasps) can suppress scale populations enough so that insecticide use is unnecessary. Some parasitic fungi can also reduce populations. However, sometimes these natural enemies are killed by adverse weather or pesticide applications, or scales infest areas where the natural enemies don't exist, which may lead to a scale outbreak. Scales that have been killed by a parasitoid usually have a small, round, pin-head sized hole in them. Predators tend to make more jagged holes when feeding. If signs of parasitism or predation are present, try to preserve the natural enemies and use less-toxic, more selective controls (e.g., horticultural oils) rather than broad-spectrum insecticides. If possible, delay applying a pesticide and give the beneficials a chance to suppress the pest population.

\section{Chemical Control}

Some insecticides labeled for scale insect control are listed in Tables 1 and 2. Timing an insecticide application properly is important. Most contact insecticides cannot penetrate the waxy covering on scale nymphs and adults, so the crawler stage is usually the best target. Monitor the crawler emergence with sticky cards, tape wrapped around a branch, or by putting an infested shoot or leaf into a baggie and watching for crawler movement. Crawler activity often coincides with the flush of new plant growth in the spring. However, some scale species 
may have overlapping generations with an extended crawler emergence period. Plants with a history of persistent scale problems (ie., camellia, hibiscus, holly, Ixora) may be treated after new growth hardens in the spring, but before scales mature.

If possible, prune infested plant parts off first to allow greater penetration of insecticides into the foliage. Spray the plants thoroughly, so that the insecticides drip or "run off" from the upper and under sides of leaves, twigs, and plant stems. Using a sticker-spreader may increase coverage and efficacy. Soil drenches of a systemic insecticide may also work well. Reapplications may be necessary, depending on the product used.

Horticultural oils kill all stages of scales that are present at application, and often give good control. Oil products labeled as summer, superior, or Volck oil are high grade and may be used on tolerant plants during either the growing or dormant seasons, but at different concentrations. Refer to the product label for guidelines on plant sensitivity and temperature limitations.

Failure of contact sprays often results from not timing the applications to coincide with crawler activity. Even when sprays are properly timed, repeated applications may be needed if crawler activity extends over time, or if populations are heavy and crawlers hide under old waxy scales.

In addition, even after armored scales are treated and killed, their waxy outer coating may remain on the plant material for weeks. There are currently no methods available to remove the waxy coverings, except by physically rubbing the scales off. When soft scales die, they often fall off the plants. Dead and living scales can be distinguished by a simple test. Squeeze some scales - dead scales are dry, but live scales exude body fluids.

\section{For More Information}

- A Guide to Scale Insect Identification (HS-817) (http://edis.ifas.ufl.edu/CH195)

- Cycad Aulacaspis Scale, Aulacaspis yasumatsui Takagi (EENY-096) (http://edis.ifas.ufl.edu/IN253)
- Cottony Cushion Scale, Icerya purchasi

Maskell (http://edis.ifas.ufl.edu/IN161)

- Division of Plant Industry, Arthropods of Florida, Volumes 3 and 11

- False Oleander Scale, Pseudaulacaspis cockerelli (Cooley) (EENY-149) (http://edis.ifas.ufl.edu/IN306)

- Green Scale, Coccus viridis (Green) (EENY-253) (http://edis.ifas.ufl.edu/IN436)

- Lobate Lac Scale, Paratachardina lobata lobata (Chamberlin) (EENY-276)

(http://edis.ifas.ufl.edu/IN471)

- Pink Hibiscus Mealybug, Maconellicoccus hirsutus (Green) (EENY-029)

(http://edis.ifas.ufl.edu/IN156)

- Red Wax Scale, Ceroplastes rubens Maskell (EENY-237) (http://edis.ifas.ufl.edu/IN393)

- Scale Insects Affecting Ornamental Plants (SP-94) (http://edis.ifas.ufl.edu/IN008)

- Scale Pests of Florida Citrus (ENY-814) (http://edis.ifas.ufl.edu/CH059)

- Sooty Mold website (http://www.broward.org/air/sootymold.htm)

- White Peach Scale, Pseudaulacaspis pentagona (Targioni) (EENY-076) (http://edis.ifas.ufl.edu/IN233)

- 2003 Florida Insect Management Guide (SP-51, online edition (http://edis.ifas.ufl.edu/MENU_GUIDE_ Insect_Management_Guide) 
Table 1. Chemical names, trade and formulations available for professional use on ornamentals.

\begin{tabular}{|c|c|c|c|c|}
\hline Chemical Name & Florida Registered Products & Chemical Class & Formulation* & Signal Word \\
\hline \multirow[t]{2}{*}{ Acephate } & Acephate Pro 75 & Organophosphate & WSP & Caution \\
\hline & Orthene TT\&O Spray 97, WSP & & WSP & Caution \\
\hline Acetamiprid & TriStar & Neonicotinoid & WSP & Caution \\
\hline Azadirachtin & Azatin XL Plus & IGR & $\mathrm{EC}$ & Caution \\
\hline \multirow[t]{3}{*}{ Bifenthrin } & Talstar Flowable & \multirow[t]{3}{*}{ Pyrethroid } & $\mathrm{F}$ & Caution \\
\hline & Talstar GC** & & $F, G$ & Caution \\
\hline & Talstar Nursery Flowable** & & $\mathrm{F}$ & Caution \\
\hline \multirow[t]{2}{*}{ Carbaryl } & Sevin SL & Carbamate & SL & Caution \\
\hline & Sevin 80 WSP & & WSP & Warning \\
\hline Clothianidin & Celero 16 & Neonicotinoid & WSG & Caution \\
\hline \multirow[t]{4}{*}{ Cyfluthrin } & Tempo 20 WP GC** & & WSP & Caution \\
\hline & Tempo 20 WP Power Pak & & WSP & Caution \\
\hline & Tempo Ultra & & SC, WP, WSP & Caution \\
\hline & Tempo 2 & & $\mathrm{EC}$ & Warning \\
\hline \multirow[t]{2}{*}{ Deltamethrin } & DeltaGard GC 5SC** & \multirow[t]{2}{*}{ Pyrethroid } & SC & Caution \\
\hline & DeltaGard T\&O 5SC & & SC & Caution \\
\hline Dinotefuran & Safari 20 SG & Neonicotinoid & $S G$ & Caution \\
\hline Fenpropathrin & Tame 2.4 EC Spray** & Fenpropathrin & EC & Warning \\
\hline Fish Oil & Organocide ${ }^{* \star \star}$ & Biorational & $E C$ & Caution \\
\hline \multirow[t]{4}{*}{ Horticultural Oil } & Triact 70 & \multirow[t]{4}{*}{ Biorational } & EC & Caution \\
\hline & Sunspray $6 \mathrm{E}$ & & $\mathrm{EC}$ & Caution \\
\hline & Sunspray $11 \mathrm{E}$ & & EC & Caution \\
\hline & Volck $^{* * *}$ & & EC & Caution \\
\hline \multirow[t]{5}{*}{ Imidacloprid } & Marathon $1 \%$ & \multirow[t]{5}{*}{ Neonicotinoid } & $G$ & Caution \\
\hline & Marathon $60 \mathrm{G} \& \mathrm{~N}$ in WSP & & WP & Caution \\
\hline & Marathon II & & $\mathrm{F}$ & Caution \\
\hline & Merit 2 & & $\mathrm{~F}$ & Caution \\
\hline & Merit 75 & & WP, WSP & Caution \\
\hline \multirow[t]{2}{*}{ Lambda-cyhalothrin } & Scimitar CS & \multirow[t]{2}{*}{ Pyrethroid } & CS & Caution \\
\hline & Scimitar WP, WSP & & WP, WSP & Warning \\
\hline \multirow[t]{6}{*}{ Malathion } & Malathion 5 & \multirow[t]{6}{*}{ Organophosphate } & SL & Warning \\
\hline & Malathon $57 \mathrm{EC}$ & & $E C$ & Caution \\
\hline & Malathion 8 & & $S L$ & Caution \\
\hline & Malathion 8-E & & $\mathrm{EC}$ & Caution \\
\hline & Malathion $8 \mathrm{~F}$ & & $\mathrm{EC}$ & Caution \\
\hline & Malathion 8 Spray & & SL & Caution \\
\hline Permethrin & $\begin{array}{l}\text { Permethrin Pro Termite-Turf } \\
\text { Ornamental }\end{array}$ & Pyrethroid & EC & Caution \\
\hline Potassium salts & Insecticidal Soap 49.52 CF & Insecticidal soap & $\mathrm{F}$ & Warning \\
\hline Pyriproxyfen & Distance Insect Growth Regulator & IGR & EC & Caution \\
\hline Thiamethoxam & Flagship 25 WG & Neonicotinoid & WG & Caution \\
\hline
\end{tabular}


Table 1. Chemical names, trade and formulations available for professional use on ornamentals.

\begin{tabular}{|c|c|c|c|c|}
\hline Chemical Name & Florida Registered Products & Chemical Class & Formulation* & Signal Word \\
\hline \multicolumn{5}{|c|}{ 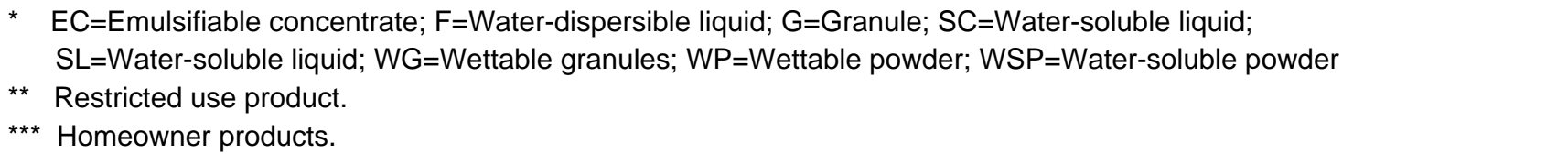 } \\
\hline \multicolumn{5}{|c|}{$\begin{array}{l}\text { Note: Only a few formulations of recommended insectiicdes are listed to serve as examples. Many others are available. } \\
\text { Read the label carefully for use directions, application techniques, irrigation requirements and precautions. }\end{array}$} \\
\hline
\end{tabular}

Table 2. Chemical names, trade and formulations available for homeowner use on ornamentals.

\begin{tabular}{|c|c|c|c|c|}
\hline Chemical Name & Florida Registered Products & Chemical Class & Formulation* & Signal Word \\
\hline Cyfluthrin & $\begin{array}{l}\text { Bayer Advanced Garden Power } \\
\text { Force Multi-Insect Killer }\end{array}$ & Pyrethroid & SL & Caution \\
\hline Dysulfoton & $\begin{array}{l}\text { Bayer Advanced Garden 2-in-1 } \\
\text { Systemic Azalea, Camellia \& } \\
\text { Rhododendon Care*** }\end{array}$ & Organophosphate & $\mathrm{G}$ & Warning \\
\hline \multirow[t]{2}{*}{ Potassium salts } & M-pede & \multirow[t]{2}{*}{ Insecticidal soap } & $\mathrm{F}$ & Caution \\
\hline & Safer's Soap & & $\mathrm{F}$ & Caution \\
\hline Pyrethroid & $\begin{array}{l}\text { Spectracide Rose \& Flower } \\
\text { Insect Spray }{ }^{\star * *}\end{array}$ & Botanical & $\mathrm{F}$ & Caution \\
\hline \multicolumn{5}{|c|}{$\begin{array}{l}\text { Note: Only a few formulations of recommended insectiicdes are listed to serve as examples. Many others are available. } \\
\text { Read the label carefully for use directions, application techniques, irrigation requirements and precautions. }\end{array}$} \\
\hline
\end{tabular}

